\title{
THE RENAL EXCRETION OF URIC ACID IN PATIENTS WITH GOUT AND IN NONGOUTY SUBJECTS * $\dagger$
}

\author{
By C. A. NUGENT aNd F. H. TYLER \\ (From the Department of Medicine and the Laboratory for the Study of Hereditary and \\ Metabolic Disorders, University of Utah College of Medicine, \\ Salt Lake City, Utah)
}

(Submitted for publication April 1, 1959; accepted July 6, 1959)

The elevation of the plasma uric acid concentration in patients with gout has been attributed by various authors to: a) decreased destruction of uric acid, $b$ ) overproduction of uric acid, or $c$ ) an abnormality in the renal excretion of uric acid (1). Decreased destruction of uric acid in patients with gout has not been found in studies utilizing labeled uric acid (2). A metabolic abnormality in the production of uric acid has been demonstrated in some patients with gout; however, increased production of uric acid has not been a uniform finding $(3,4)$.

The possibility that there might be a specific abnormality in the renal excretion of uric acid by patients with gout has been investigated on numerous occasions. The most extensive recent investigations of the renal excretion of uric acid were carried out by Coombs and co-workers (5), Tal-

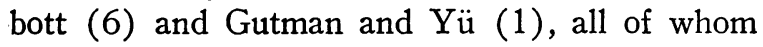
agreed that there is no essential difference in the manner in which uric acid is excreted by subjects with gout and by normal subjects. However, their studies were performed while the normal subjects and gouty patients had markedly different plasma uric acid concentrations. In the present investigation of the renal excretion of uric acid, patients with gout were studied under control conditions and nongouty subjects were studied before and after they had been given uric acid or its precursors in amounts great enough to elevate their plasma uric acid concentrations to values comparable to those of the gouty patients.

\section{METHODS}

Six male patients with gout were studied. One patient was studied on two occasions. Their clinical status is

* Presented in part at the Western Society for Clinical Research, January, 1959, Carmel, Calif.

$\dagger$ This work was supported by Grants A-2 and A-1828 from the National Institute of Arthritis and Metabolic Diseases, National Institutes of Health, United States Public Health Service, Bethesda, Md. indicated in Table I. In every case, a typical history of acute gouty arthritis was obtained. Gouty patients with renal failure, heart disease or advanced age were purposely excluded from the study. Ten studies were performed on seven nongouty male subjects. The clinical information on this group is also given in Table I.

The control studies were carried out while all of the gouty patients and nongouty subjects were taking their usual diets. They were instructed, however, to eat no high purine foods and to take no uricosuric drugs for at least one month before the studies. The test studies were done after the nongouty subjects had been given uric acid or one of its precursors in addition to their diet. The nature of these dietary supplements is indicated in Table I. Two nongouty subjects were studied after they had been fed a high purine diet. The high purine diet was isocaloric with the control diet and contained the same proportions of fat, carbohydrate and protein, but sardines, liver and anchovies were used to provide 90 per cent of the protein. All of the remaining subjects were given ribose nucleic acid packed in gelatin capsules and administered in four equal doses with meals and at bedtime. One normal subject was also given uric acid and desoxyribose nucleic acid. With one exception, each subject received the dietary supplement for a three day period. On the morning of the fourth day, three hours before the first clearance period, the subjects were given their usual morning dose of the dietary supplements. The two subjects on the high purine diet, however, received no food before the renal function studies on the fourth day. Subject 7 was given ribose nucleic acid for five days and after his usual morning dose of ribose nucleic acid the renal function studies were repeated on the sixth day.

All the studies were started between 7:00 and 8:00 a.m. and completed between 10:00 a.m. and 12:00 noon. The subjects were hydrated by the oral administration of 600 to $800 \mathrm{ml}$. of water in the first hour and 150 to $250 \mathrm{ml}$. of water every half hour during the remainder of the study. Standard clearance methods were used (7). Catheterization of the bladder, however, was done only in those cases in which the estimated residual bladder urine exceeded $20 \mathrm{ml}$. (8). The urine collection periods varied from 10 to 20 minutes in the catheterized patients and 15 to 30 minutes in the voiding patients. All clearances in this report represent the average of the values from two to four sequential clearance periods. Two to four plasma specimens were analyzed during each study. The individual inulin clearances did not vary more than 10 per 
TABLE I

Clinical data and dietary regimens

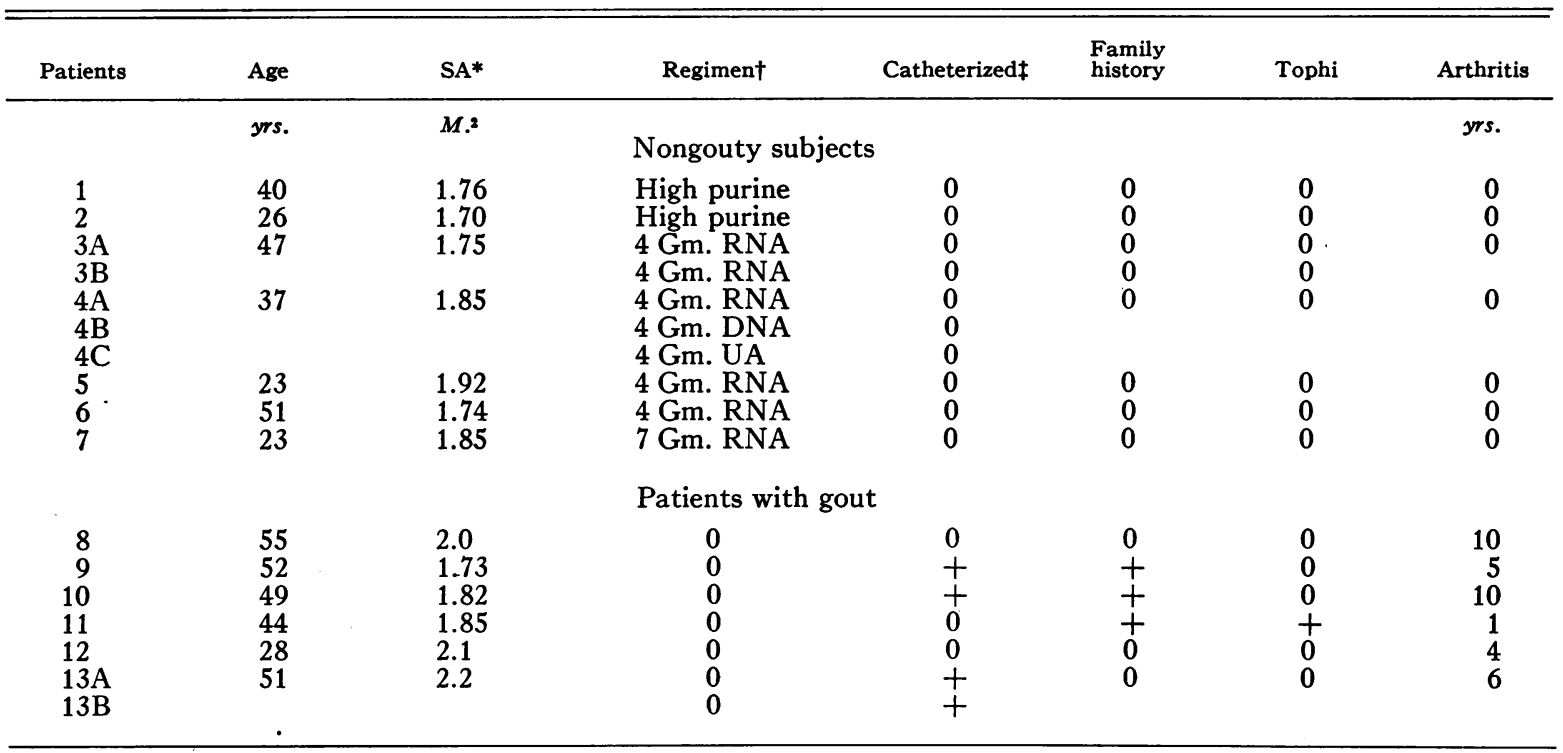

* SA = surface area.

$\dagger$ RNA = ribose nucleic acid, DNA = desoxyribose nucleic acid, UA = uric acid.

$\ddagger \mathrm{A}$ " $+"$ sign in this column indicates that the individual was catheterized during the renal function study.

cent from the mean of the particular study with four exceptions. In these four studies, the uric acid to inulin clearance ratios for the individual periods did not vary more than 5 per cent from the mean of the particular study.

Blood specimens were mixed with heparin and the plasma was separated by centrifugation. The enzymatic ${ }^{1}$ spectrophotometric method of Praetorius was used for the determination of uric acid (9). The plasma uric acid determinations reported here were performed directly on the specimens without prior protein precipitation. In addition, enzymatic spectrophotometric uric acid determinations were done on protein-free filtrates of plasma prepared by the method of Forsham, Thorn, Prunty and Hills (10). None of the urine specimens contained protein by the heat and acetic acid test. The uric acid determinations were carried out directly on diluted urine specimens. Inulin was determined by the method of Young and Raisz (11). The anthrone precipitated when used in the concentrations suggested by these authors. Their method worked satisfactorily, however, with 3.2 $\mathrm{Gm}$. of anthrone in place of the recommended $4 \mathrm{Gm}$. per L. of acid solution and $1.25 \mathrm{ml}$. of unknown solution in place of the recommended $2 \mathrm{ml}$. of unknown per $10 \mathrm{ml}$. of anthrone solution (12). Twenty-four hour urine collections were obtained during the control period and on the last day of each oral loading period. The method of Phillips (13) was used for urine creatinine determinations.

1 The uricase was obtained through Worthington Biochemical Corporation, Freehold, N. J.

\section{RESULTS}

The results of the renal function studies (Table II) have been corrected to a body surface area of $1.73 \mathrm{M} .^{2}$. No correction was made for the results of the 24 hour urine collections. One nongouty subject had an average inulin clearance of $82 \mathrm{ml}$. per minute. The history, physical examination, urinalysis and intravenous pyelogram on this subject were all within normal limits. One additional nongouty subject and four of the gouty patients had inulin clearances below $100 \mathrm{ml}$. per minute. In no case, however, was the inulin clearance outside the range of variation for the age or more than two standard deviations below the mean of the subjects studied by Davies and Shock (14).

The mean plasma uric acid concentration was $5.6 \mathrm{mg}$. per $100 \mathrm{ml}$. in the nongouty subjects and $9.2 \mathrm{mg}$. per $100 \mathrm{ml}$. in the gouty patients under control conditions. Two of the nongouty subjects had plasma uric acid concentrations of 7.1 and 7.2 mg. per $100 \mathrm{ml}$. In our laboratory, using fresh whole plasma, uric acid concentrations of this level are occasionally seen in normal subjects. These values exceed what is usually considered 


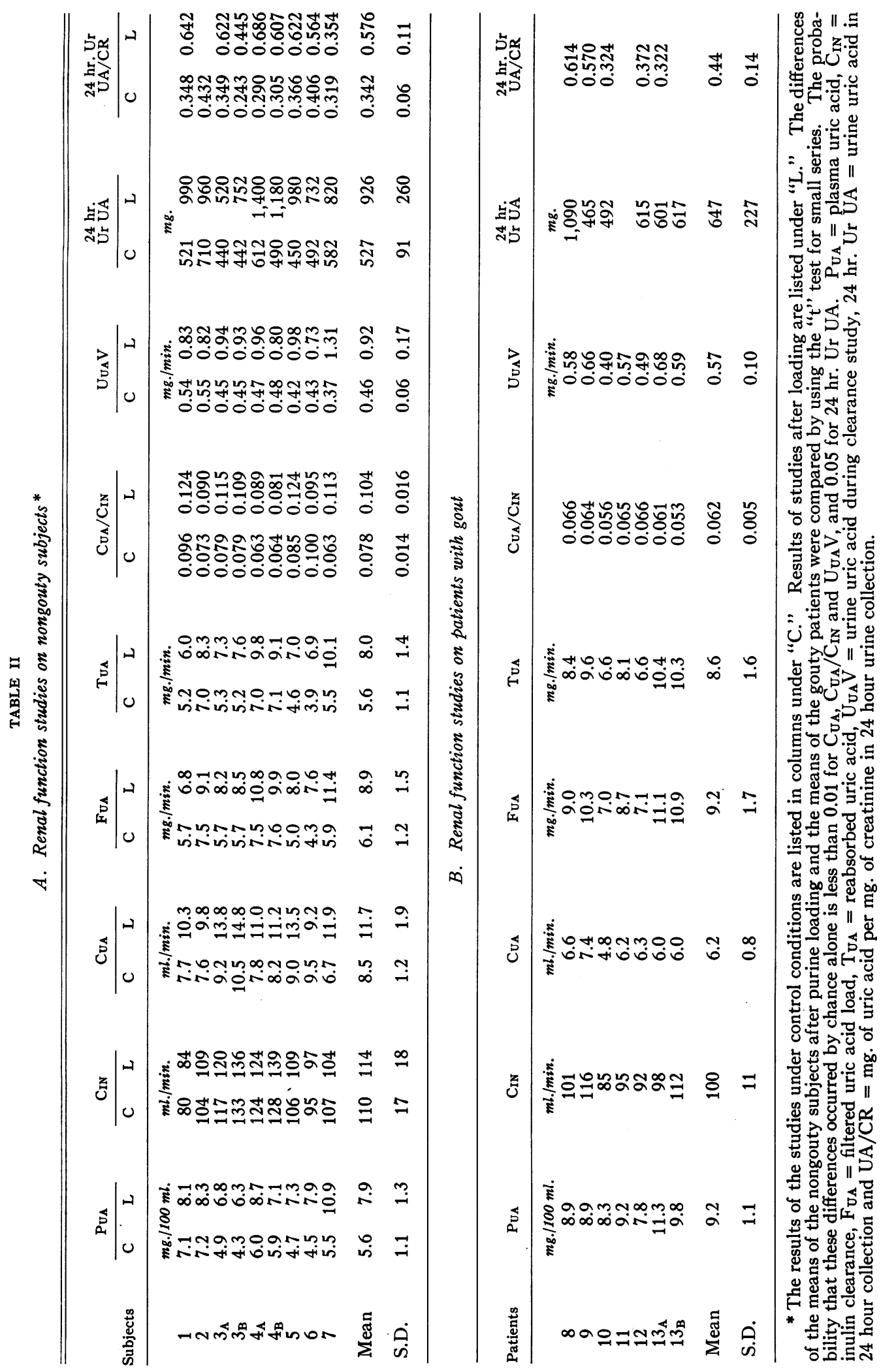


the upper limits of the normal range of uric acid in protein-free serum filtrates (1). Other investigators have also noted the slightly higher uric acid values obtained with enzymatic spectrophotometric methods on whole plasma (15).

The mean uric acid clearance and proportion of filtered uric acid excreted by the patients with gout was slightly lower and the mean filtered, reabsorbed and excreted uric acid was slightly higher than in the nongouty subjects (Table II and Figure 1). There was some overlap of individual values between the two groups of subjects in every measured parameter with the exception of the plasma uric acid concentration. The mean 24 hour urine uric acid excretion was higher in the patients with gout than in the nongouty group. One patient with gout excreted 1,090 mg. of uric acid per day. All of the other patients with gout for whom we have data excreted between 465 and $617 \mathrm{mg}$. of uric acid per day, which is approximately the same range as that of the nongouty subjects. In view of the difficulty of collecting 24 hour urine specimens on nonhospitalized subjects, uric acid to creatinine ratios were determined. These were similar in the two groups under control conditions. That the majority of subjects with gout do not excrete an abnormally large amount of uric acid each day in their urine is shown by our data and in the extensive investigations reported by Gutman and $\mathrm{Y} \ddot{\mathrm{u}}(1)$.

Daily administration of $4 \mathrm{Gm}$. of uric acid by mouth had little effect on the plasma uric acid con-

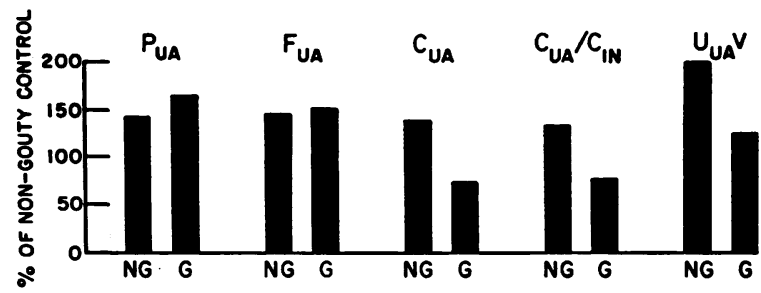

Fig. 1. Renal Function of Nongouty Subjects (NG) After Oral Loading With Purines Compared With That of Patients With Gout (G) Under Control Conditions

The height of each column represents the mean results expressed as per cent of the nongouty control values. $\mathrm{P}_{\mathrm{OA}_{\mathrm{A}}}=$ plasma uric acid concentration, $\mathrm{F}_{\mathrm{CA}}=$ filtered uric acid load, $\mathrm{C}_{\mathrm{UA}}=$ uric acid clearance, $\mathrm{C}_{\mathrm{IN}}=$ inulin clearance and $U_{U A} V=$ rate of uric acid excretion.

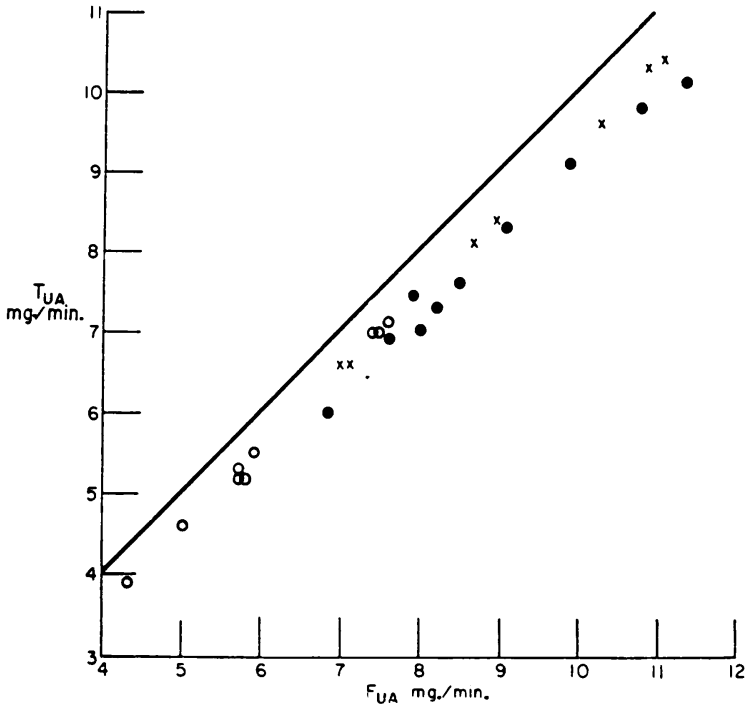

Fig. 2. The Relation of Tubular Reabsorption of Uric AcID ( $\left.\mathrm{T}_{\mathrm{UA}}\right)$ to Filtered URIC ACID LoAd $\left(F_{\text {UA }}\right)$

The heavy diagonal line indicates total reabsorption of the filtered load of uric acid. The results of the studies on the nongouty subjects under control conditions are indicated by open circles and after uric acid loading by solid circles. The values in the patients with gout studied under control conditions are indicated by cross marks.

centration or the 24 hour urine urate excretion. ${ }^{2}$ The high purine diet and $4 \mathrm{Gm}$. per day of desoxyribose nucleic acid were moderately effective while $4 \mathrm{Gm}$. per day of ribose nucleic acid usually resulted in a striking rise in plasma uric acid concentration and in 24 hour urine uric acid excretion. The greatest increase in plasma uric acid concentration occurred in the subject who was given $7 \mathrm{Gm}$. of ribose nucleic acid per day for

${ }^{2}$ In Study $4 \mathrm{c}$, after $4 \mathrm{Gm}$. of uric acid a day for three days, the plasma uric acid concentration was $6.4 \mathrm{mg}$. per $100 \mathrm{ml}$. and the filtered uric acid $7.9 \mathrm{mg}$. per minute. These values differed little from the plasma uric acid concentration and filtered uric acid load of the control studies and were far below the levels of the patients with gout. Therefore, the results of the $4 \mathrm{c}$ study are not included in Table II but are plotted in Figures 2, 3 and 4. No control studies were done immediately before the oral administration of uric acid in the case of $4 \mathrm{c}$, but the results of the $4_{A}$ and $4_{B}$ control studies were very similar to one another and therefore have been used as a baseline. It can be seen that the changes after oral uric acid, although slight, were in the same direction as those induced by the other dietary supplements. Four Gm. of uric acid a day in other subjects induced similar changes in plasma and urine uric acid. 


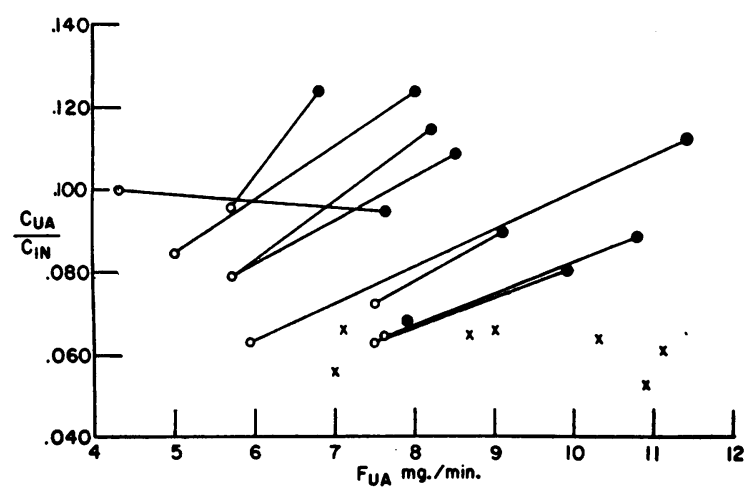

Fig. 3. The Relation of the Proportion of Filtered Uric Acid Excreted ( $\mathrm{C}_{\mathrm{UA}} / \mathrm{C}_{\mathrm{IN}}$ ) to the FilTERED URIC ACID LOAd ( $\left.\mathrm{F}_{\mathrm{UA}}\right)$

Symbol conventions are the same as in Figure 2. See text for discussion.

five days. No investigation was made of the role of variations in absorption or destruction in the gastrointestinal tract or variations in the degree of conversion to uric acid in determining the differences between the response to the various dietary regimens.

High purine intake in the nongouty subjects resulted in a rise of the mean plasma uric acid concentration to $7.9 \mathrm{mg}$. per $100 \mathrm{ml}$. Although, under these conditions, the mean filtered uric acid load was almost identical with the control value in the gouty patients, the nongouty subjects excreted uric acid at two times their control rate of excretion and their proportion of filtered uric acid excreted and their uric acid clearance far exceeded that of the gouty patients (Figure 1 ). The mean 24 hour urine uric acid excretion of the nongouty subjects rose well above their control level and exceeded the mean of the gouty patients.

Figure 2, in which renal tubular reabsorption of uric acid is plotted as a function of filtered uric acid load, reveals no gross difference between the gouty and the nongouty groups. The heavy diagonal line indicates total reabsorption of the filtered uric acid. The proportion of the filtered uric acid excreted is indicated by the vertical distance between a point and the heavy line compared to the vertical distance from the heavy line to the level of no reabsorption of uric acid. Some investigators have used similar data, plotted as in Figure 2, to support the notion that the percentage of the filtered load of urate reabsorbed in gout does not differ from that of normal subjects at equivalent filtered urate loads (1). Since only a very small proportion of the total filtered urate load is excreted either by gouty patients or by normal subjects, a plot of the data in this fashion tends to obscure differences in the proportion of filtered uric acid excreted. When the proportion of the filtered load of urate excreted (uric acid/inulin clearance ratio) is plotted as a function of filtered urate load (Figure 3), a difference is apparent between the nongouty subjects and the patients with gout. Under control conditions, the proportion of filtered uric acid excreted is slightly lower in the patients with gout than in the nongouty subjects. Oral administration of uric acid precursors to nongouty subjects resulted in the elevation of their filtered urate load to the range of those of the patients with gout. Under these circumstances the nongouty subjects excreted a higher proportion of their filtered urate load than did the patients with gout who had comparable filtered loads. All but one of the nongouty subjects excreted a higher proportion of their filtered load of uric acid during the experimental than during the control periods. The values for two gouty patients in Figure 3 lie in the area occupied by the nongouty subjects under control conditions. These two individuals, Patients 10 and 12 , had the lowest plasma uric acid concentrations of the patients with gout. In addition, Patient 10 had the lowest inulin clearance among the patients with gout.

In Figure 4, the proportion of filtered uric acid excreted is plotted as a function of the plasma uric

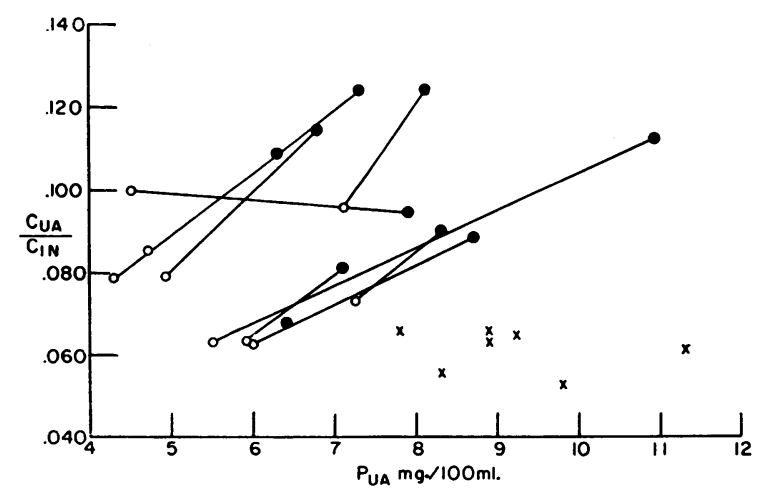

Fig. 4. The Relation of the Proportion of Filtered Uric Acid Excreted $\left(\mathrm{C}_{\mathrm{DA}} / \mathrm{C}_{\mathrm{IN}}\right)$ to the Plasma Uric Acid Concentration ( $\mathrm{P}_{\mathrm{UA}}$ )

Symbol conventions are the same as in Figure 2. 
acid concentration. The same general relations between the two groups shown in Figure 3 can be seen here. The control data of the nongouty subjects and gouty patients are better separated in Figure 4 than in Figure 3. Possibly the proportion of filtered urate excreted is a function of the plasma urate concentration rather than of the filtered load.

The results of the plasma uric acid determinations after protein precipitation differed from those reported in this paper only in that the plasma uric acid concentrations were 9 per cent lower, with a standard deviation of 4 per cent. This resulted in corresponding changes in the amounts of uric acid filtered and reabsorbed and in the uric acid clearance, but the relations between the various values and their appearance after plotting showed little difference from the results reported here.

\section{DISCUSSION}

It is usually stated that the plasma uric acid is completely filterable by the glomeruli, that a varying proportion of the filtered uric acid is reabsorbed by the renal tubules and that none is excreted by the tubules (16). There is considerable experimental evidence that plasma uric acid is completely filterable (17). As judged by the work of one group of investigators, who used paper electrophoresis with many different buffers and a wide variety of experimental conditions including variation in $\mathrm{pH}$, ionic strength, temperature and potential gradients, no inhomogeneity of the plasma uric acid has been demonstrated (18). It is not so generally accepted that there is no renal tubular excretion of uric acid in humans. The anomalous decrease in the clearance of uric acid which uniformly occurs after the administration of small doses of a wide variety of agents which increase urate clearance at higher doses (1) is one of the facts which is difficult to explain if one accepts the view that uric acid is not excreted by the tubules. However, for convenience, and in the absence of conclusive evidence that the assumptions stated above are not correct, we will accept them for the purpose of this discussion.

Many investigations of renal function in gout have been carried out in the past. These have included study of the effect of feeding uric acid precursors (19). In these investigations, how- ever, there has been great variation in the methods used for measurement of uric acid concentration and glomerular filtration rate. Because of their large number and the great differences in techniques employed, a discussion of all of the reports will not be presented here. The studies of Coombs and co-workers (5), of Talbott (6) and of Gutman and $Y \ddot{u}$ (1) were carried out on large numbers of patients and inulin was used for the determination of glomerular filtration rates. In particular, the studies of Gutman and Yü (1) seem most suitable for comparison with our own. These investigators corrected for nonurate chromogen in urine by using uricase and demonstrated agreement of their colorimetric method with enzymatic spectrophotometric measurements (20). Some of the results of Gutman and Yü's studies are shown in Table III for comparison with the data of the present investigation.

The results of the renal function studies under control conditions reported here are similar to the findings of Coombs and associates (5), Talbott (6) and Gutman and Yü (1). The means of the uric acid clearance, proportion of filtered uric acid excreted and rate of uric acid excretion are only slightly different in the nongouty and gouty groups. and there is some overlap of individual values. These findings have led many observers in the past to conclude that there is no abnormality in the renal excretion of uric acid by patients with gout $(1,5,21)$. Oral purine loading of the nongouty subjects enabled us to study renal function in nongouty subjects and in gouty patients at comparable plasma uric acid concentrations. Under these conditions, the uric acid clearance, proportion of filtered uric acid excreted and rate of uric acid excretion by the nongouty subjects were well above the levels observed in the gouty patients. Since the filtered uric acid load of the nongouty subjects after purine loading was approximately the same as that of the gouty patients, the difference in renal excretion of uric acid between the two groups must be attributed to a lower tubular reabsorption of uric acid by the nongouty subjects.

The rise in 24 hour urine uric acid excretion in the nongouty subjects after high purine intake, although large, is not as great as one would expect from the doubling of the rate of uric acid excretion during the renal clearance studies. Several 
TABLE III

Renal function*

\begin{tabular}{|c|c|c|c|c|c|}
\hline & \multirow{2}{*}{\multicolumn{2}{|c|}{ Data of Gutman and $Y \ddot{u}(1)$}} & \multicolumn{3}{|c|}{ Present data } \\
\hline & & & \multicolumn{2}{|c|}{ Nongouty males } & \multirow[b]{2}{*}{ Gout } \\
\hline & $\begin{array}{c}\text { Nongouty } \\
\text { males }\end{array}$ & Gout & Control & $\begin{array}{l}\text { Urate } \\
\text { load }\end{array}$ & \\
\hline $\mathrm{P}_{\mathrm{UA}}(m g . / 100 m l)$. & $\begin{array}{r}5.6 \\
\pm 1.3\end{array}$ & $\begin{array}{r}9.0 \\
\pm 1.4\end{array}$ & $\begin{array}{r}5.6 \\
\pm 1.1\end{array}$ & $\begin{array}{r}7.9 \\
\pm 1.3\end{array}$ & $\begin{array}{r}9.2 \\
\pm 1.1\end{array}$ \\
\hline $\mathrm{C}_{\mathrm{IN}}(\operatorname{ml} . / \min )$. & & $\begin{array}{r}98.5 \\
\pm 17.7\end{array}$ & $\begin{array}{r}110 \\
\pm 17\end{array}$ & $\begin{array}{r}114 \\
\pm 18\end{array}$ & $\begin{array}{r}100 \\
\pm 11\end{array}$ \\
\hline $\mathrm{C}_{\mathrm{UA}}(m l . / m i n)$. & $\begin{array}{r}8.7 \\
\pm 2.5\end{array}$ & $\begin{array}{r}7.5 \\
\pm 2.4\end{array}$ & $\begin{array}{r}8.5 \\
\pm 1.2\end{array}$ & $\begin{array}{r}11.7 \\
\pm 1.9\end{array}$ & $\begin{array}{r}6.2 \\
\pm 0.8\end{array}$ \\
\hline $\mathrm{F}_{\mathrm{UA}}(m g . / m i n)$. & $\begin{array}{r}6.3 \\
\pm 1.4\end{array}$ & $\begin{array}{r}10.1 \\
\pm 2.8\end{array}$ & $\begin{array}{r}6.1 \\
\pm 1.2\end{array}$ & $\begin{array}{r}8.9 \\
\pm 1.5\end{array}$ & $\begin{array}{r}9.2 \\
\pm 1.7\end{array}$ \\
\hline $\mathrm{T}_{\mathrm{UA}}(m g . / m i n)$. & $\begin{array}{r}5.8 \\
\pm 1.4\end{array}$ & $\begin{array}{r}9.5 \\
\pm 2.6\end{array}$ & $\begin{array}{r}5.6 \\
\pm 1.1\end{array}$ & $\begin{array}{r}8.0 \\
\pm 1.4\end{array}$ & $\begin{array}{r}8.6 \\
\pm 1.6\end{array}$ \\
\hline $\mathrm{C}_{\mathrm{UA}} / \mathrm{C}_{\mathrm{IN}}$ & $\begin{array}{r}0.076 \\
\pm 0.024\end{array}$ & $\begin{array}{r}0.068 \\
\pm 0.021\end{array}$ & $\begin{array}{r}0.078 \\
\pm 0.014\end{array}$ & $\begin{array}{r}0.104 \\
\pm 0.016\end{array}$ & $\begin{array}{r}0.062 \\
\pm 0.005\end{array}$ \\
\hline $\mathrm{U}_{\mathrm{UA}} \mathrm{V}(m g . / m i n)$. & $\begin{array}{r}0.493 \\
\pm 0.159\end{array}$ & $\begin{array}{r}0.663 \\
\pm 0.235\end{array}$ & $\begin{array}{r}0.46 \\
\pm 0.06\end{array}$ & $\begin{array}{r}0.92 \\
\pm 0.17\end{array}$ & $\begin{array}{r}0.57 \\
\pm 0.10\end{array}$ \\
\hline $24 \mathrm{Hr}$. Ur UA (mg.) & $\begin{array}{r}418 \\
\pm 70\end{array}$ & $\begin{array}{l}497 \\
\text { (range, } 170 \\
\text { to } 1,520 \text { ) }\end{array}$ & $\begin{array}{r}527 \\
\pm 91\end{array}$ & $\begin{array}{r}926 \\
\pm 260\end{array}$ & $\begin{array}{r}647 \\
\pm 227\end{array}$ \\
\hline
\end{tabular}

* The results are expressed as the means and the standard deviations. The abbreviations are the same as those used in Table II.

explanations seem plausible. There are many extraneous factors which influence the excretion of uric acid. One would expect dietary changes (22, 23) and exercise $(24,25)$ to be more prominent variables during a 24 hour urine collection period than during a renal clearance study. One of these effects is strikingly illustrated in Subject 7 . This subject hiked in mountainous country during the day of his urine collection period after purine loading. The prolonged and striking effect of exercise in decreasing the excretion of uric acid may well account for the relatively small increase in 24 hour urine uric acid excretion that was associated with a marked rise in plasma uric acid concentration and rate of uric acid excretion during the final renal function study in this subject.

The nongouty subjects were fed uric acid or its precursors for periods of only three days. It is conceivable that in time the normal subjects would have "adapted" to prolonged elevation of their plasma uric acid concentration and eventually would have excreted a smaller proportion of filtered uric acid. Repeated renal function studies were done on four nongouty subjects maintained for periods of one month on 4 to $8 \mathrm{Gm}$. of ribonucleic acid per day (26). There was no significant change in their renal excretion of uric acid associated with the passage of time.

In the past few years overproduction of uric acid has been regarded by many investigators as the basis for hyperuricemia in gout $(1,27,28)$. The presence of tophaceous deposits around joints, uric acid calculi and large amounts of uric acid in the urine of some patients with gout led Garrod to conclude that "an undue formation of this substance would favor the occurrence of the disease" (29). However, there are many patients with gout in whom overproduction of uric acid is not readily apparent. The majority of gouty patients do not excrete abnormally large amounts of urate in their urine, many do not have tophi (1), and in some patients without tophi the miscible uric acid pool is only 3 to $5 \mathrm{Gm}$. $(30,31)$. The prolonged increase in urate excretion induced by administration of uricosuric agents to some patients with nontophaceous gout suggests that these patients have urate deposits that are not clinically obvious (32). The increased incorporation of 
glycine into uric acid demonstrable in some patients with gout has been regarded as supporting the overproduction theory as the basis for hyperuricemia. In discussing overincorporation, Wyngaarden makes clear the distinction between early overincorporation of glycine into urinary uric acid, a defect actually demonstrated in some gouty patients, and overproduction of uric acid. Early overincorporation of glycine and significant overproduction of uric acid are not necessary concomitants (28).

Regardless of whether overproduction of uric acid occurs in all patients with gout, the data of the present investigation do not support the overproduction theory as the exclusive basis for hyperuricemia in gout. In the present study, the nongouty subjects required oral purines in amounts great enough to double their milligram per minute excretion rate of urates and far exceed the excretion rate of the gouty patients in order to produce hyperuricemia of similar magnitude to that observed in the gouty patients. Excluding individuals with renal disease, if the elevation of the serum uric acid in gout were simply due to overproduction of uric acid, then gouty patients should uniformly excrete larger than normal amounts of uric acid in their urine.

It seems very likely that gout is fundamentally the result of a metabolic abnormality. In view of the present facts, however, it does not seem likely that the hyperuricemia of most patients with gout is solely attributable to overproduction of uric acid. Abnormal renal excretion of uric acid is an important cause of hyperuricemia in some patients with gout. In addition to the overproduction of uric acid demonstrable in some patients, a metabolic defect in gout might affect the plasma urate concentration by: $a$ ) the production of a nonurate substance affecting renal excretion of uric acid and resulting in hyperuricemia; $b$ ) the production of uric acid that was bound to protein or differed from the remainder of the plasma uric acid in some other respect; or $c$ ) a metabolic defect might affect the kidneys in some more direct manner. We have no evidence to support any of these possibilities.

\section{CONCLUSIONS}

1. Renal function studies were performed on seven nongouty male subjects on 10 occasions and on six gouty male patients on seven occasions under control conditions. The inulin and uric acid clearances, proportion of filtered uric acid excreted and rate of uric acid excretion were similar in the two groups.

2. Uric acid precursors were administered orally to the nongouty subjects for three to five day periods in order to increase their plasma uric acid concentrations and filtered uric acid loads to the range found in the patients with gout. Under these conditions, the nongouty subjects reabsorbed a smaller proportion of their filtered uric acid and achieved a uric acid clearance and uric acid excretion rate well above the levels observed in the gouty patients.

3. It is concluded that abnormal renal excretion of uric acid is one important cause of hyperuricemia in some patients with gout.

\section{REFERENCES}

1. Gutman, A. B., and Yü, T. F. Renal function in gout. Amer. J. Med. 1957, 23, 600.

2. Buzzard, J., Bishop, C., and Talbott, J. H. The fate of uric acid in the normal and gouty human being. J. chron. Dis. 1955, 2, 42.

3. Seegmiller, J. E., Laster, L., and Liddle, L. V. Failure to detect consistent overincorporation of glycine-1-C ${ }^{14}$ into uric acid in primary gout. Metabolism 1958, 7, 376.

4. Wyngaarden, J. B. Normal glycine- $\mathrm{C}^{14}$ incorporation into uric acid in gout. Metabolism 1958, 7, 374.

5. Coombs, F. S., Pecora, L. J., Thorogood, E., Consolazio, W. V., and Talbott, J. H. Renal function in patients with gout. J. clin. Invest. 1940, 19, 525.

6. Talbott, J. H. Gout. New York, Oxford University Press, 1943.

7. Smith, H. W. Principles of Renal Physiology. New York, Oxford University Press, 1956.

8. Mills, J. N., Thomas, S., and Yates, P. A. Assessment of voluntary bladder emptying in man. $\mathrm{J}$. Physiol. (Lond.) 1955, 129, 408.

9. Praetorius, E. An enzymatic method for the determination of uric acid by ultra-violet spectrophotometry. Scand. J. clin. Lab. Invest. 1949, 1, 222.

10. Forsham, P. H., Thorn, G. W., Prunty, F. T. G., and Hills, A. G. Clinical studies with pituitary adrenocorticotropin. J. clin. Endocr. 1948, 8, 15.

11. Young, M. K., Jr., and Raisz, L. G. An anthrone procedure for determination of inulin in biological fluids. Proc. Soc. exp. Biol. (N. Y.) 1952, 80, 771.

12. Fingl, E. Personal communication.

13. Phillips, R. A. in Peters, J. P., and Van Slyke, D. D. Quantitative Clinical Chemistry (Methods), Army 
ed. Baltimore, Williams and Wilkins Co., vol. 2, 1943.

14. Davies, D. F., and Shock, N. W. Age changes in glomerular filtration rate, effective renal plasma flow and tubular excretory capacity in adult males. J. clin. Invest. 1950, 29, 496.

15. Wyngaarden, J. B. Intermediary purine metabolism and the metabolic defects of gout. Metabolism 1957, 6, 224.

16. Berliner, R. W., Hilton, J. G., Yü, T. F., and Kennedy, T. J., Jr. The renal mechanism for urate excretion in man. J. clin. Invest. 1950, 29, 396.

17. Yü, T. F., and Gutman, A. B. Ultrafiltrability of plasma uric acid in man. Proc. Soc. exp. Biol. (N. Y.) 1953, 84, 21.

18. Salteri, F., Cirla, E., and Fasoli, A. Electromigration on filter paper of uric acid from serum and synovial fluid. Science 1958, 127, 85.

19. Brochner-Mortensen, $K$. On variations in the uric acid clearance after administration of purine with special reference to the threshold problem. Acta med. scand. 1939, 99, 525.

20. Yü. T. F., and Gutman, A. B. Quantitative analysis of uric acid in blood and urine. Methods and interpretation. Bull. rheum. Dis. (Diag. Proc. Suppl.) 1951, 7, 17.

21. Stettin, DeW., Jr., Talbott, J. H., Seegmiller, J. E., Wyngaarden, J. B., and Laster, L. The pathogenesis of gout. Metabolism 1957, 6, 88.

22. Quick, A. J. The relationship between chemical structure and physiological response. J. biol. Chem. 1932, 98, 157.
23. Lockie, L. M., and Hubbard, R. S. Gout: Changes in symptoms and purine metabolism produced by high fat diets in four gouty patients. J. Amer. med. Ass. 1935, 104, 2072.

24. Nichols, J., Miller, A. T., Jr., and Hiatt, E. P. Influence of muscular exercise on uric acid excretion in man. J. appl. Physiol. 1950-51, 3, 501.

25. Yü, T. F., Sirota, J. H., Berger, L., Halpern, M., and Gutman, A. B. Effect of sodium lactate infusion on urate clearance. Proc. Soc. exp. Biol. (N. Y.) 1957, 96, 809.

26. Nugent, C. A., and Tyler, F. H. In preparation.

27. Talbott, J. H. Gout. New York, Grune and Stratton, 1957.

28. Wyngaarden, J. B. Overproduction of uric acid as the cause of hyperuricemia in primary gout. J. clin. Invest. 1957, 36, 1508.

29. Garrod, A. B. Observations on certain pathological conditions of the blood and urine in gout, rheumatism and Bright's disease. Med. chir. Trans. 1848, 31, 83.

30. Benedict, J. D., Forsham, P. H., and Stetten, DeW., $\mathrm{Jr}$. The metabolism of uric acid in the normal and gouty human studied with the aid of isotopic uric acid. J. biol. Chem. 1949, 181, 183.

31. Bishop, C., Garner, W., and Talbott, J. H. Pool size, turnover rate, and rapidity of equalization of injected isotopic uric acid in normal and pathological subjects. J. clin. Invest. 1951, 30, 879.

32. Gutman, A. B., and Yü, T. F. Gout, a derangement of purine metabolism. Advanc. intern. Med. 1952, $5,227$.

\section{SPECIAL NOTICE TO SUBSCRIBERS}

Post Offices will no longer forward the Journal when you move.

Please notify The Journal of Clinical Investigation, Business

Office, 333 Cedar Street, New Haven 11, Conn., at once when you have a change of address, and do not omit the zone number if there is one. 